[11] Grynchenko, N., Tyutyukova, D., Pyvovarov, P. (2017). Study of quality indicators of fermented-milk cheese obtained from skimmed milk at a controlled content of calcium. Eastern-European Journal of Enterprise Technologies, 6 (11 (90)), 11-21. doi: 10.15587/1729-4061.2017.117136

[12] Grynchenko, N., Tyutyukova, D., Pyvovarov, P. (2017). Study of influence of calcium content in milk on quality indicators of cottage cheese. EUREKA: Life Sciences, 6, 22-28. doi: 10.21303/25045695.2017 .00510

[13] Lindmark-Mansson, H., Fonden, R., Pettersson, H.-E. (2003). Composition of Swedish dairy milk. International Dairy Journal, 13 (6), 409-425. doi: 10.1016/s0958-6946(03)00032-3

[14] Nelson, B. K., Barbano, D. M. (2005). A Microfiltration Process to Maximize Removal of Serum Proteins from Skim Milk Before Cheese Making. Journal of Dairy Science, 88 (5), 1891-1900. doi: 10.3168/ jds.s0022-0302(05)72865-4

\title{
INVESTIGATION OF THE ROLE OF PLASTICIZERS IN FILM-FORMING COATS FOR PROTECTING COOLED MEAT
}

\author{
Andrii Kyshenia \\ Department of meat, fish and seafood technology \\ Odessa National Academy of Food Technologies \\ 112 Kanatna str., Odessa, Ukraine, 65039 \\ andrii.kyshenia@gmail.com \\ Lydmila Vinnikova \\ Department of meat, fish and seafood technology \\ Odessa National Academy of Food Technologies \\ 112 Kanatna str., Odessa, Ukraine, 65039 \\ Tat'yana Volovik \\ Department of biochemistry, microbiology and physiology of nutrition \\ Odessa National Academy of Food Technologies \\ 112 Kanatna str., Odessa, Ukraine, 65039 \\ tavol0929@gmail.com \\ Yevhenii Kotliar \\ Department of technology of milk, fats and perfume and kosmetycheskyh funds \\ Odessa National Academy of Food Technologies \\ 112 Kanatna str., Odessa, Ukraine, 65039 \\ yevhenii11@ukr.net

\section{Kateryna Garbazhiy} \\ Department of Security, Expertise and Commodity Research \\ Odessa National Academy of Food Technologies \\ 112 Kanatna str., Odessa, Ukraine, 65039 \\ garbazhiykat@gmail.com
}

\footnotetext{
Abstract

As a result of theoretical studies on problems of protection and prolongation of storage terms of meat, it was revealed, that one of promising directions is to use protecting coats, based on natural biopolymers.

The topicality of this study is in studying film-forming coats, based on natural polysaccharides, because they have high mechanical indices, absence of a smell, taste and are subjected to biological destruction. For regulating mechanical properties, the
} 
composition of film-creating coats is added with plasticizers of different origins.

The aim of this work is in describing characteristics of food films, based on carrageenan, sodium alginate and plasticizers of different origins.

There were mechanical, rheological properties of protecting coats. The comparative characteristic of these properties, depending on an added plasticizer, was realized. The type and mechanisms of interaction of components of the film-forming coat and plasticizers were completely described. The viscosity of the film-forming coat with a plasticizer has less values comparing with other solutions. Adding plasticizers resulted in increasing the film elasticity, but at the same time some increase of the firmness was observed.

Film-forming coats with adding a plasticizer had a higher limit of fluidity, so they were firmer than complex film-forming coats without a plasticizer. From the other side, deformation values of film-forming coats without adding a plasticizer were higher than ones of complex film-forming coats with adding a plasticizer, because they were firmer.

The study of physical properties of developed film-forming coats, based on hydrocolloids, demonstrated that coats with a plasticizer have more gas permeability.

According to the results, obtained at experiments it was established, that the film-forming coat, based on sodium alginate, carrageenan and glycerin, has best mechanical, physical and rheological indices.

Keywords: film-forming coats, plasticizer, storage term of meat, synergism, sodium alginate, hydrocolloids.

\section{Introduction}

The increase of consumption demand for high-quality products with a long storage life stimulated the development of conserved meat products that keep their natural and fresh look for a long time. For this aim, the essential scientific research work, devoted to the usage of food films and coats, was realized during the last 30 years [1-3].

A food coat or film were defined as follows: a thin continual layer of food materials, fit for food, processed together with its edible content, and created or applied on food products or food components. Its function is to create a barrier of mass exchange (water, gas and lipids) that acts as a carrier of food ingredients and admixtures (pigments, aromatizers and so on) or for providing mechanical and anti-microbial protection [4].

Structural and barrier properties of food films depend on certain parameters, such as a film-forming solution viscosity, procedure of film formation, its thickness, water-absorption characteristics of used plasticizers and so on [5].

Plasticizers - are small, non-shifting molecules with a low molecular weight that can be added to films for increasing flexibility and decreasing brittleness [6, 7]. These molecules work, decreasing inter-molecular efforts along the polymer chain. It is also known, that they decrease the temperature of materials' glass formation [8-10].

Plasticizers can also demonstrate a certain negative influence on food films. There are the increase of permeability for gas, solutions and water steam, and also the decrease of film coupling. It is important to note, that a plasticizer with a concentration, higher than the established one, is not consistent with the biopolymer, and phases separation can take place [11-14].

The viscosity of film-forming materials plays an important role in controlling film properties. Researchers [15] demonstrated the importance of the behavior of the flow of dispersedly formed films, where dispersion characteristics have an important influence on the surface smoothness and look of a coat. The coat quality in the solid state depends on properties of the fluidity of a liquid film.

Steam-permeability is the most widely studied characteristic of food films [16-20], mainly because of the key role of water in worsening the interaction. Factors that influence the steam-permeability of food films include: their composition, temperature and relative humidity. Work [21] is one of few, devoted to the temperature influence of the steam-permeability of food films. It also studies the relative humidity influence on the steam-permeability of food films. Work [22] described the influence of the molecular mass of methylcellulose (MC) and hydroxypropyl cellulose (HPC) on oxygen permeability and steam one, and also the firmness limit to 
disruption and elongation of food films. Water steam absorption data characterize aquation properties of a polymer.

Mechanical, barrier properties, resistance of many food films to permeability of gas or soluble substances mainly depend on environmental conditions, such as relative humidity and temperature. At the same time mechanical properties include firmness to disruption, firmness to pricking, relative elongation, brittleness of obtained films [23, 24].

A disadvantage of film-forming coats, formed only of hydrocolloids, is low values of mechanical parameters. For regulating mechanical properties, plasticizers of different origins are added to the composition of film-forming coats. Taking it into account, the elaboration, theoretical and experimental studies of natural coats is an urgent direction for the development of the branch.

The aim of this work is to create and describe characteristics of food films, based on carrageenan, sodium alginate and plasticizers of different origins. It allows to understand the behavior of the hydrocolloid mixture depending on an added plasticizer. And also to establish the rational plasticizer for using it at creating protective films at storage of cooled meat.

\section{Materials and methods}

The materials of the studies were:

- water (SS 2874-82);

- carrageenan (SS 33310-2015);

- sodium alginate (SS 33310-2015);

- polyethylene glycol (SS 8433-81);

- sorbite (SS P 53904-2010);

- glycerin (SS 6824-96).

All raw materials, used in the conducted studies, corresponded to existent normative documents in Ukraine by parameters of safety and quality, permitted for usage by the Health Protection Ministry of Ukraine.

For studying characteristics, there were prepared film-forming solutions in the following concentration (sodium alginate $2 \%$, carrageenan $1 \%$, plasticizer $3 \%$ for $100 \mathrm{ml}$ of water) Different plasticizers were used as a factor of comparison at the studies. Solutions were made in the following ratio of components:

1) sodium alginate $2 \%+$ carrageenan $1 \%$;

2) sodium alginate $2 \%+$ carrageenan $1 \%+$ sorbite $3 \%$;

3) sodium alginate $2 \%+$ carrageenan $1 \%+$ polypropylene glycol $3 \%$;

4) sodium alginate $2 \%+$ carrageenan $1 \%+$ glycerin $3 \%$.

Viscosimeter. For measuring viscosity, there was chosen a viscosimeter «Brookfield» (model No.: DV-II programmed rheometer, Brookfield Engineering Laboratories, INC, Middleboro, USA) using a thermoplatform of SC4-27 block with the temperature interval $23-25{ }^{\circ} \mathrm{C}$. Under conditions of measuring there was established the increment speed $=1,00$; acceleration speed $=0,005$; set speed $=5,00$; waiting $=50,0$, these parameters were calculated taking into account recommendation of the producer of the viscosmeter as to the studied material. Two measurements were made for each sample of the created film.

The principle of the viscosimeter's work is based on measuring a force, necessary for stopping a cylinder, paced in a revolving glass with the analyzed medium. The force, necessary for stopping the turning cylinder, is proportional to the viscosity. The viscosimeter consists of a primary transformer and measuring block with the numerical indication of viscosity.

For determining the initial shift tension (fluidity limit), the change of the turning speed is provided in the viscosimeter, and the algorithm of calculating the initial shift tension using viscosity values, obtained at different speeds, is given.

The viscosimeter has a temperature sensor that allows to determine the temperature value of the analyzed medium before measuring viscosity. The special construction of the glass provides stability of keeping the temperature of the analyzed medium during a long time. 


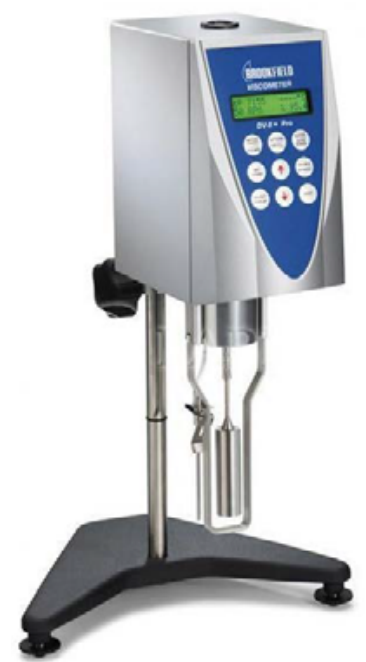

Fig. 1. Rotation viscosimeter Brookfield model №: DV-II (USA)

Determination of steam permeability of films. For this aim, a sample was pressurized to the side surface of the test dish (Fig. 2) with water solution. The dish with the sample was placed in the drying chamber at $\mathrm{t}=23{ }^{\circ} \mathrm{C}$, this temperature was chosen in correspondence to the one of the external environment for keeping experimental conditions at weighing the dish. Besides the dish with the studied sample, a dehumidifier was placed in the drying chamber $\left(\mathrm{CaCl}_{2}\right)$. As a result of the difference between partial pressures of water steam, the water steam flow passes through the sample. For determining the water steam flow density, the dish with the sample was weighed with 1 hour cyclicity, till achieving the balanced state. The study was conducted according to SS R EN 12086.

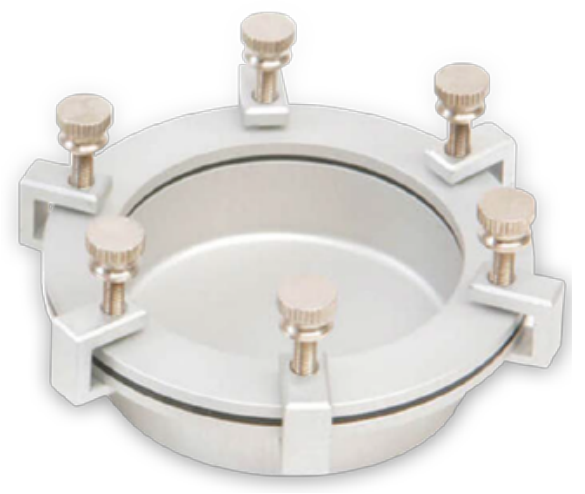

Fig. 2. Dish for measuring steam permeability

The mass change of the dish with the sample $\left(\mathrm{G}_{1,2}\right)$, for each sample in the given time interval was calculated by the formula:

$$
\mathrm{G}_{1,2}=\frac{\left|\mathrm{m}_{2}-\mathrm{m}_{2}\right|}{\mathrm{t}_{2}-\mathrm{t}_{1}},
$$

where $\mathrm{m}_{1}-$ mass of the dish with the sample in the time moment $\mathrm{t}_{1}, \mathrm{mg} ; \mathrm{m}_{2}-$ mass of the dish with the sample in the time moment $t_{2}, m g ; t_{1}$ and $t_{2}$ - time moments of successive weighing of the dish with the sample, hour.

The relative humidity (W) was calculated by the formula:

$$
\mathrm{W}=\frac{\mathrm{G}}{\mathrm{S}_{\text {mean }} \cdot \Delta \mathrm{P}},
$$


where $\mathrm{S}_{\text {mean }}$ - mean arithmetic value of areas of the upper and low parts of the sample, influenced by steam, $\mathrm{m}^{2} ; \Delta \mathrm{P}$ - difference of tensions depending of testing conditions, $\mathrm{Pa}$.

Study of mechanical characteristics of the film-forming coat. Testing of samples of the edible film-forming coat for determining firmness characteristics is realized using the experimental equipment with the digital program management, correspondent to these aims. Experiments were conducted on the device Instron_8802 (ISTRON Ltd., USA), by the standard ASTM D 882-12, with a sensor of measuring an effort (dynamometer) $500 \mathrm{~N}$. The sample was stretched by shifting the active seizure with the speed $20 \mathrm{~mm} / \mathrm{min}$. In the process of testing the recording of the deformation diaphragm was realized, according to shift indices. 8 samples were tested totally, the characteristics of firmness $\sigma_{t}$, Young's firmness modulus $E$ and one of the relative elongation of the sample after disruption $\delta$ were obtained according to the results of testing.

The samples were cut of the studied film by the preliminarily prepared mould. It was produced of plastics for not to injury the film. The obtained samples have the following sizes: length $-250 \mathrm{~mm}$, width $-23 \mathrm{~mm}$, these sizes are grounded by characteristics of a fixer, where the film is placed.

The area of the transversal cut $F$ of the samples is calculated after distinct measurements and written in the protocol of experiments.

The sample is horizontally placed in the fixer, after that the chain is vertically placed on the testing set.

After switching on testing, the effort value on the sample, shift of the active seizure and also the deformation diagram in coordinates "tension-deformation" $(\sigma-\varepsilon)$ are recorded in on-line regime.

After destructing the sample, all data are recorded and the value of the temporal resistance $\sigma_{t}$ is deduced. Young's firmness modulus is calculated by the initial "direct" part of the deformation diagram, and the relative elongation $\delta$ is measured by parts of the sample, taken from the fixer.
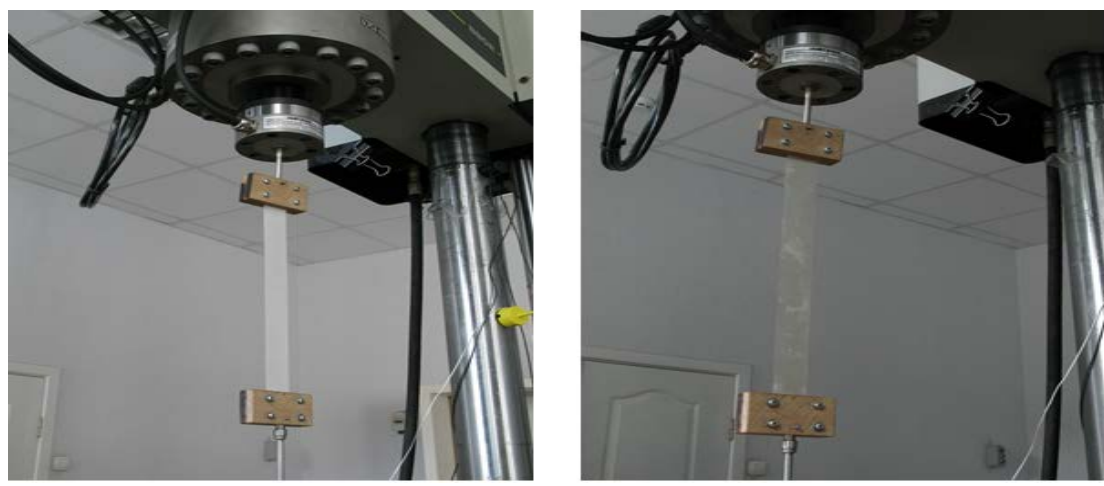

Fig. 3. The study of mechanical characteristics of the film-forming coat

Determination of the firmness to pricking. The analyzer Instron was also used for checking the pricking firmness of films. The measuring top with a ball of $5 \mathrm{~mm}$ was used in this test for breaking uncut films. The testing speed was $10 \mathrm{~mm} / \mathrm{s}$, and the functioning effort $-5 \mathrm{~g}$. The force, distance and effort, needed for pricking films, were determined of the created graph force-distance. In total 8 films were tested again for each study.

\section{Results}

Rheological properties of film-forming solutions in the highest degree are characterized by viscosity that directly influences structural, mechanical and barrier properties of coats. The curves of stable flows of film-forming solutions are demonstrated on Fig. 4.

We must pay attention to the fact that all studies for measuring viscosity of solutions of film-forming coats were conducted at the same temperature $\left(18^{\circ} \mathrm{C}\right)$. 


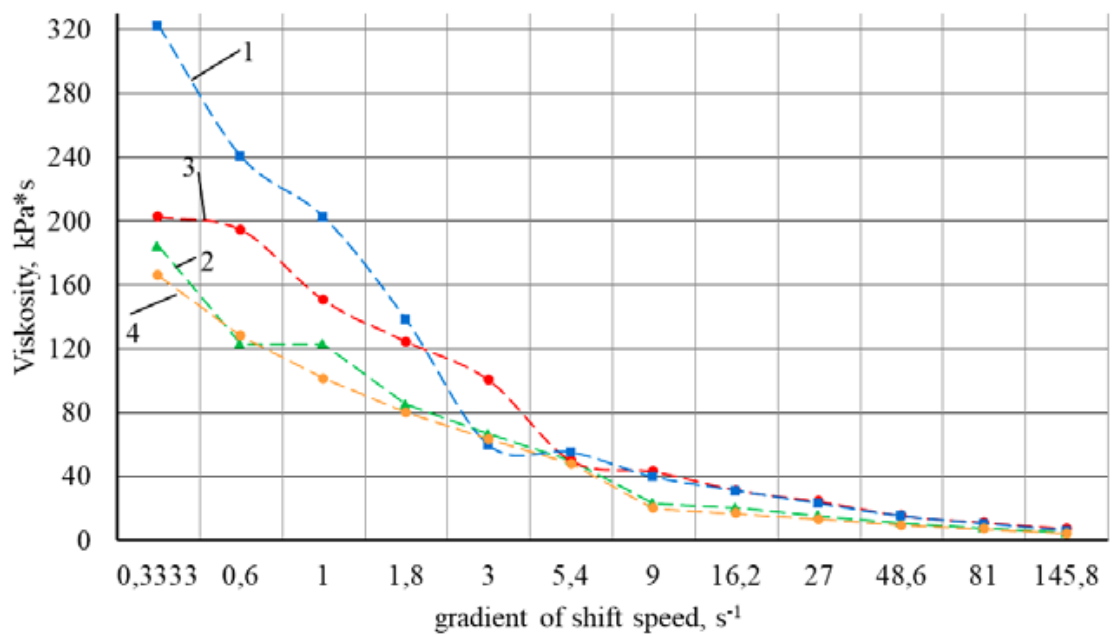

Fig. 4. Viscosity as a function of shift speed of hydrocolloids solution: 1 - sodium alginate + carrageenan, 2 - sodium alginate + carrageenan + sorbite, 3 - sodium alginate + carrageenan + polypropylene glycol, 4 - sodium alginate + carrageenan + glucerin

Mechanical parameters of film-forming coats were checked on the universal testing device «Instron Universal Testing Instrument» (model 8802, ISTRON Ltd., USA) by the standard ASTM D882-83.

Steam permeability was studied for assessing the effectiveness of barrier characteristics of films. One of important properties of film-forming coats is the ability to keep moisture, in such a way preventing losses of meat mass at storage.

At the same time steam permeability was determined, because the access of oxygen is needed was saving the natural color of meat. A product must not lose its natural properties at storage, but must not absorb smells from the environment.

Table 1

Quality parameters of film-creating coats

\begin{tabular}{|c|c|c|c|c|c|}
\hline \multicolumn{2}{|c|}{ Parameters/No. of sample } & 1 & 2 & 3 & 4 \\
\hline \multirow{3}{*}{$\begin{array}{l}\text { Characteristic of } \\
\text { film }\end{array}$} & Width, mm & \multicolumn{4}{|c|}{23} \\
\hline & Thickness, mm & 0,07 & 0,07 & 0,09 & 0,08 \\
\hline & Length, mm & \multicolumn{4}{|c|}{250} \\
\hline \multirow{6}{*}{ Research results } & Maximal effort at destruction $\mathrm{P}_{\max }, \mathrm{N}$ & 29,54 & 19,47 & 31,92 & 33,79 \\
\hline & Temporal resistance, $\mathrm{MPa}$ & 8,34 & 9,35 & 11,74 & 12,10 \\
\hline & Young's modulus, MPa & 504,95 & 851,49 & 659,22 & 798,50 \\
\hline & Relative elongation at disruption, & 9,20 & 7,17 & 6,36 & 11,23 \\
\hline & Firmness to pricking & 8,95 & 12,56 & 11,78 & 10,90 \\
\hline & Steam permeability, $\mathrm{mg} /\left(\mathrm{m}^{2} \cdot\right.$ hour $\left.\cdot \mathrm{Pa}\right)$ & 2440 & 3150 & 2870 & 2680 \\
\hline
\end{tabular}

\section{Conclusions}

Food films, based on polysaccharides and plasticizers, were obtained and characterized in this study for getting information about packing properties of these films. There were also studied their permeability characteristics. Carrageenan and sodium alginate were used as materials that form edible films, using distilled water as a solvent, and plasticizers of different origins (glycerin, sorbite, polyethylene glycol).

The viscosity of film-forming solutions was determined by the influence of the flow behavior on film formation properties. As a result of measuring viscosity, solutions demonstrated non-Newton behavior that is pseudo-plasticity by decreasing viscosity at increasing the shift speed. 
The properties of steam permeability of films were assessed as a function of the solution concentration, film thickness and type of the polymer of films. The study of physical properties of developed film-forming coats, based on hydrocolloids, demonstrated that coats with a plasticizer are more steam permeable.

The mechanical experiments demonstrated that films with a plasticizer have the stronger and firmer construction comparing with ones without a plasticizer because of the high disruption firmness and Young's firmness modulus.

As a result of all studies, all studied film-forming coats are suitable for producing good polymers. At that each film has different properties. The film-forming coat with a plasticizer can give films with the high sorption of water steam and low barrier properties as to water steam, at that these films are well characterized by such mechanical properties as the high firmness and solid structure. From the other side, film-forming coats without a plasticizer are suitable for films with lower sorption ability and high steam isolation. For both film types: different film-forming concentrations of the solution resulted in forming films with similar properties.

The further work about these types of edible films must be connected with using them for cooled meat, meat products for assessing their influence on certain characteristics of products, such as texture, microbial activation, freshness, storage term and controlled moisture release.

\section{References}

[1] Perez-Gago, M. B., Krochta, J. M.; Gennadios, A. (Ed.) (2002). Formation and Properties of Wheat Gluten Films and Coatings Protein-Based Films and Coatings. Boca Raton: CRC Press, 159-180. doi: 10.1201/9781420031980.ch6

[2] Krochta, J. M.; Gennadios, A. (Ed.) (2002). Proteins as Raw Materials for Films and Coatings. Protein-based Films and Coatings Gennadios. Boca Raton: CRC Press, 1-41. doi: 10.1201/ 9781420031980.ch1

[3] Sperling, L. H. (2006). Introduction to Physical Polymer Science. New York: John Wiley \& Sons, Inc, 11-15.

[4] Fillips, G. O., Vil'iams, P. A.; Kochetkova, A. A. (Ed.) (2006). Spravochnyk po gidrokolloidam. Saint Petersburg: GIORD, 536.

[5] Vinnikova, L. G., Kyshenya, A. V. (2016). Biozakhisne pokryttya dlya podovzhennya terminu zberi-gannya myasa. Wspolpraca Europejska, 1, 97-107.

[6] Madhumita, R., Madhumita, R., Ramalingam, C. (2012). Bioedible coating of meat using garlic, cinnamon and turmeric. European Journal of Experimental Biology, 2 (5), 1439-1443.

[7] Li, J.-M., Nie, S.-P. (2016). The functional and nutritional aspects of hydrocolloids in foods. Food Hydrocolloids, 53, 46-61. doi: 10.1016/j.foodhyd.2015.01.035

[8] Scetar, M., Kurek, M., Galic, K. (2010). Trends in meat and meat products packaging. Croatian Journal of Food Science and Technology, 2 (1), 32-48.

[9] Snezhko, A. G., Gubanova, M. I., Semenov, G. V. (2011). Perspektivnye napravleniya primeneniya pokrytiy iz prirodnykh polimerov. Myasnaya industriya, 8, 43-46.

[10] Gohil, R. M. (2010). Synergistic blends of natural polymers, pectin and sodium alginate. Journal of Applied Polymer Science, 120 (4), 2324-2336. doi: 10.1002/app.33422

[11] Bilbao-Sainz, C., Avena-Bustillos, R. J., Wood, D. F., Williams, T. G., McHugh, T. H. (2010). Composite Edible Films Based on Hydroxypropyl Methylcellulose Reinforced with Microcrystalline Cellulose Nanoparticles. Journal of Agricultural and Food Chemistry, 58 (6), 3753-3760. doi: 10.1021/jf9033128

[12] Lima, A. M., Cerqueira, M. A., Souza, B. W. S., Santos, E. C. M., Teixeira, J. A., Moreira, R. A., Vicente, A. A. (2010). New edible coatings composed of galactomannans and collagen blends to improve the postharvest quality of fruits - Influence on fruits gas transfer rate. Journal of Food Engineering, 97 (1), 101-109. doi: 10.1016/j.jfoodeng.2009.09.021

[13] Jirukkakul, N. (2013). A study of Mu Yor sausage wraps using chitosan films incorporating garlic oil, lemon grass oil and galangal oil. International Food Research Journal, 20, 1199-1204.

[14] Shon, J.-H., Kim, J.-H., Eo, J.-H., Choi, Y.-H. (2012). Effect of Soy Protein Isolate Coating on Meat Quality of Pork Fresh Cut during Refrigerated Storage. Journal of Applied Biological Chemistry, 55 (1), 27-34. doi: 10.3839/jabc.2011.055 
[15] Lima, A. M. F., Soldi, V., Borsali, R. (2009). Dynamic light scattering and viscosimetry of aqueous solutions of pectin, sodium alginate and their mixtures: effects of added salt, concentration, counterions, temperature and chelating agent. Journal of the Brazilian Chemical Society, 20 (9), 1705-1714. doi: 10.1590/ s0103-50532009000900020

[16] Tang, X., Alavi, S., Herald, T. J. (2008). Effects of plasticizers on the structure and properties of starch-clay nanocomposite films. Carbohydrate Polymers, 74 (3), 552-558. doi: 10.1016/j.carbpol.2008.04.022

[17] Atares, L., Bonilla, J., Chiralt, A. (2010). Characterization of sodium caseinate-based edible films incorporated with cinnamon or ginger essential oils. Journal of Food Engineering, 100 (4), 678-687. doi: 10.1016/j.jfoodeng.2010.05.018

[18] Oms-Oliu, G., Soliva-Fortuny, R., Martin-Belloso, O. (2008). Using polysaccharide-based edible coatings to enhance quality and antioxidant properties of fresh-cut melon. LWT - Food Science and Technology, 41 (10), 1862-1870. doi: 10.1016/j.lwt.2008.01.007

[19] Chen, J. L., Zhao, Y. (2012). Effect of Molecular Weight, Acid, and Plasticizer on the Physicochemical and Antibacterial Properties of $\beta$-Chitosan Based Films. Journal of Food Science, 77 (5), 127-136. doi: $10.1111 / \mathrm{j} .1750-3841.2012 .02686 . \mathrm{x}$

[20] Khan, M. I., Adrees, M. N., Tariq, M. R., Sohaib, M. (2013). Application of edible coating for improving meat quality. Pakistan Journal of Food Sciences, 23, 71-79.

[21] Evtushenko, M. V., Bredihina, O. V. (2013). Hranenie morozhenoi produkcii iz obektov vodnyh biologicheskih resursov s ispol'zovaniem plenochnyh modificirovannyh pokrytii. Rybnoe hoziaistvo, 3, 103-104.

[22] Pestina, A. A. (2011). Perspektivi vikoristannia sistem na osnovi al'gintu natriiu ta pektinu v tekhnologii kharchovih produktiv. Nizkotemperaturni ta kharchovi tehnologii u XXI stolitti, 255-257.

[23] Kambulova, Yu. V., Sokolovska, I. O. (2014). Doslidzhennya reologichnykh vlastyvostei rozchyniv pektyniv, alginatu natriyu ta yikh kompleksiv. Kharchova nauka i tekhnologiya, 26, 68-73.

[24] Dhanapal, A., Sasikala, P., Rajamani, L., Kavitha, V., Yazhini, G., Banu, M. S. (2012). Edible films of Polysaccharides. Food science and Quality Management, 13, 57-60.

\title{
STUDY OF THE PERMEABILITY DEGREE OF THE ALGINATE-CALCIUM TUNIC OF CAPSULES UNDER CONDITIONS OF THE USE OF MIXED IONOTROPIC THERMOTROPIC GELATION
}

\author{
Olga Neklesa \\ Department of technology of bread, confectionery, pasta and food concentrates \\ Kharkiv State University of Food Technology and Trade \\ 333 Klochkivska str., Kharkiv, Ukraine, 61051 \\ olgapyvovarova52@ukr.net
}

\begin{abstract}
Today scientific base of technologies of capsulated products by methods of ionotropic structuring allows to create a new segment of food industry of the Ukrainian food market. Implementation of such innovations creates preconditions for developing principles of food raw materials processing, constructing the new equipment and successful competition at the world food market.

The article studies the influence of agar and low-etherified pectin in the composition of capsules, based on gel $\mathrm{Alg}_{2} \mathrm{Ca}$ on the mass-transfer of substances at the expanse of thermotropic gelation. Obtained results testify to the possibility to create systems with different permeability for high- and low-molecular substances on this base. Studied systems are characterized with different speeds of releasing active substances that may be used for providing their prolonged effect on the human organism. Modification of alginate-calcium tunics of capsules with the internal fatty raw material content by using the method of mixed gelation allows to correct structural-mechanical and, as a result, organoleptic and quality parameters of capsulated
\end{abstract}

